\title{
Ultrarapid caspase-3 dependent apoptosis induction by serine/threonine phosphatase inhibitors
}

\author{
KE Fladmark ${ }^{1}$, OT Brustugun ${ }^{1}$, R Hovland ${ }^{1}$, R Bøe', \\ BT Gjertsen ${ }^{1}$, B Zhivotovsky² and SO Døskeland ${ }^{\star, 1}$ \\ 1 Cell Biology Research Group, Department of Anatomy and Cell Biology, \\ University of Bergen, Årstadveien 19, N-5009 Bergen, Norway \\ 2 Institute of Environmental Medicine, Division of Toxicology, Karolinska \\ Institute, S-171 77 Stockholm, Sweden \\ * Corresponding author: S0 Døskeland, University of Bergen, Department of \\ Anatomy and Cell Biology, Årstadveien 19, N-5009 Bergen, Norway. \\ Tel: +4755586376; Fax: +4755586360; E-mail: stein.doskeland@pki.uib.no
}

Received 8.3.99; revised 20.7.99; accepted 26.8.99

Edited by $\mathrm{S}$ Kumar

\begin{abstract}
The protein phosphatase (PP) inhibitors nodularin and microcystin-LR induced apoptosis with unprecedented rapidity, more than $50 \%$ of primary hepatocytes showing extensive surface budding and shrinkage of cytoplasm and nucleoplasm within $2 \mathrm{~min}$. The apoptosis was retarded by the general caspase inhibitor Z-VAD.fmk. To circumvent the inefficient uptake of microcystin and nodularin into nonhepatocytes, toxins were microinjected into 293 cells, Swiss 3 T3 fibroblasts, promyelocytic IPC-81 cells, and NRK cells. All cells started to undergo budding typical of apoptosis within 0.5-3 min after injection. This was accompanied by cytoplasmic and nuclear shrinkage and externalization of phosphatidylserine. Overexpression of Bcl-2 did not delay apoptosis. Apoptosis induction was slower and Z-VAD.fmk independent in caspase- 3 deficient MCF-7 cells. MCF-7 cells stably transfected with caspase-3 showed a more rapid and ZVAD.fmk dependent apoptotic response to nodularin. Rapid apoptosis induction required inhibition of both PP1 and PP2A, and the apoptosis was preceded by increased phosphorylation of several proteins, including myosin light chain. The protein phosphorylation occurred even in the presence of apoptosis-blocking concentrations of Z-VAD.fmk, indicating that it occurred upstream of caspase activation. It is suggested that phosphatase-inhibiting toxins can induce caspase-3 dependent apoptosis in an ultrarapid manner by altering protein phosphorylation.
\end{abstract}

Keywords: apoptosis; protein phosphorylation; caspases; phosphatase inhibitors; cyanobacterial toxins

Abbreviations: PP1, phosphoprotein phosphatase type 1; PP2A, phosphoprotein phosphatase type $2 \mathrm{~A}$

\section{Introduction}

Regulated ('programmed') cell death often occurs by a morphologically distinct series of events, termed apoptosis. ${ }^{1,2}$ Apoptotic cells are recognized by cell shrinkage, cell surface budding and chromatin hypercondensation. Specific cleavage of DNA, ${ }^{2} \mathrm{RNA},{ }^{3}$ and 'flipping' of phospholipids to the external face of the cell membrane ${ }^{4,5}$ are also commonly associated with apoptosis. Caspases are believed to be instrumental in the execution of regulated death. So far 14 members (caspase $1-14$ ) of the caspase family have been described. $^{6,7}$ Some of these, like procaspase- 8 and -2 , can undergo autoactivation through multimerization, ${ }^{8,9}$ and in turn activate downstream procaspase ${ }^{10-12}$ and other proapoptotic proteins. ${ }^{13}$ The $\mathrm{Bcl}-2$ protein family contains members (Bcl2 , $\mathrm{Bcl}-\mathrm{x}_{\mathrm{L}}$ ) that can protect against apoptosis. ${ }^{16}$ Actions of $\mathrm{Bcl}-$ 2 include the prevention of mitochondrial release of cytochrome $c^{15,16}$ as well as of the apoptogenic action of cytoplasmic cytochrome $c{ }^{17}$ The mammary carcinoma cell line MCF-7 lacks both procaspase-3 and the ability to undergo apoptosis in response to injected cycochrome $c^{18,19}$ and is a model to test for death which is independent of cytochrome $c$ and caspase-3.

Altered protein phosphorylation ('dysphosphorylation') is known to be an important modulator of apoptosis induction and possibly apoptosis execution. This can occur either through action on protein kinases or protein phosphatases. $^{20-22}$ It is intriguing that serine/threonine protein phosphatases 1 and 2A (PP1 and PP2A) are targeted by an array of chemically distinct microbial toxins. ${ }^{23}$ We and others have shown that cell-permeant protein phosphatase inhibitors like okadaic $\mathrm{acid}^{24,25}$ are general inducers of apoptosis. ${ }^{26-29}$ We have postulated that the inhibitors act by short-cutting normal pathways of apoptosis induction. ${ }^{23}$ A logical consequence of this would be that they could act faster than other apoptosis-inducers, if allowed immediate access to the intracellular compartment. This hypothesis was tested in the present study (1) by microinjecting a number of cell types with the water soluble phosphatase inhibitors ${ }^{23}$ nodularin and microcystin, and (2) by exposing primary rat hepatocytes to high concentrations of these toxins in the medium. Hepatocytes are unique among mammalian cells in having an efficient transport system for microcystin and nodularin. ${ }^{30}$ The question of whether protein phosphorylation was involved in toxin-induced death was addressed by temporal comparison of the cellular phosphoprotein pattern (studied by two-dimensional electrophoresis) with the development of apoptotic indices of cell death. It was also of interest to know whether inhibition of PP1, PP2A or both was required for rapid apoptosis induction, and whether the phosphorylation changes were upstream or downstream of caspase activation. 


\section{Results}

\section{Intracellularly delivered protein phosphatase inhibitors induce apoptosis ultrarapidly}

Inhibitors of protein phosphatases $2 \mathrm{~A}$ and 1 can induce apoptotic cell death in most, if not all, higher eukaryotic cells. ${ }^{27,29}$ Studies of the rate of apoptosis induction by phosphatase inhibitors have been hampered by the relatively slow cellular uptake of the commonly used membrane permeant inhibitors, tautomycin, okadaic acid and calyculin $\mathrm{A}^{31}$ and by the lack of cellular uptake of the polar inhibitors microcystin-LR and nodularin in all cells except hepatocytes. ${ }^{30}$ In introductory experiments cells were microinjected with all the mentioned inhibitors to test how rapidly cells could develop apoptosis following abrupt inhibition of their phosphatases. Tautomycin, okadaic acid and calyculin A all failed to produce apoptosis even when injected at concentrations up to $1 \mathrm{mM}$ (data not shown). This could be due to rapid efflux or to preferential distribution to intracellular membranes of these hydrophobic compounds. Microinjection of either microcystin-LR (not shown) or nodularin produced extensive budding and rounding of Swiss 3T3 fibroblasts, human HEK 293 cells, and normal rat kidney (NRK) cells in a remarkably short time (Figure 1). Semilogarithmic plots allowed a quantitative estimate of apoptosis progression as a function of time (Figures $1 \mathrm{~A}-$ $\mathrm{C}, 2 \mathrm{~A}, 3 \mathrm{~A})$. The rectilinear nature of the plots showed that the entrance of cells into apoptosis obeyed first order kinetics. The apparent lag period before the onset of apoptosis was particularly short in HEK 293 cells $(<20 \mathrm{~s})$ and fibroblasts (about $30 \mathrm{~s})$. Such rapid apoptosis induction has not been reported previously.

The 'flipping' of phosphatidylserine from the inner to the outer side of the plasma membrane has been found to be associated with apoptosis. ${ }^{4,5}$ To test for this phenomenon fibroblasts were injected with nodularin while bathed in a medium containing FITC-annexin $\mathrm{V}$, which binds with high affinity to phosphatidylserine. When FITC-annexin $\mathrm{V}$ was added to already apoptotic cells, labeling was observed after 0.5-1 min, suggesting that external phosphatidylserine should be observable within less than $1 \mathrm{~min}$. Surface fluorescence could be seen in injected cells shortly after they had started budding (Figure 1A, inset). When the lag of staining is considered, it appeared that phosphatidylserine became externalized about simultaneously with cell budding. The staining was not due to penetration of FITC-annexin $V$ into the cell with staining of intracellular phosphatidylserine, since the apoptotic cells excluded propidium iodide. Only cells that were deliberately injected under supraoptimal pressure to produce necrosis stained positively with both annexin $\mathrm{V}$ and propidium iodide (Figure 1A).

Condensation of chromatin was judged by fluorescence microscopy of cells stained with bisbenzimide to visualize DNA. In Swiss 3T3 fibroblasts, human HEK 293 cells, and normal rat kidney (NRK) cells chromatin condensation occurred a few minutes after injection of nodularin (Figure 1A, inset; data not shown).

\section{The ultrarapid apoptosis induction by phosphatase inhibitors depends on caspase- 3 and is not prevented by $\mathrm{Bcl}-2$ overexpression}

Since only a limited number of cells can be sampled within the first few minutes after microinjection, biochemical studies required a cell model where the toxin could act without microinjection. Ultrarapid induction of apoptosis could be achieved in hepatocytes without microinjection: nearly half of the hepatocytes showed apoptotic budding already after $2 \mathrm{~min}$ exposure to medium with $16 \mu \mathrm{M}$ microcystin-LR (Figure $2 \mathrm{~A}$ ) or $5 \mu \mathrm{M}$ nodularin (Figure $3 \mathrm{~A}$ ). The morphological changes

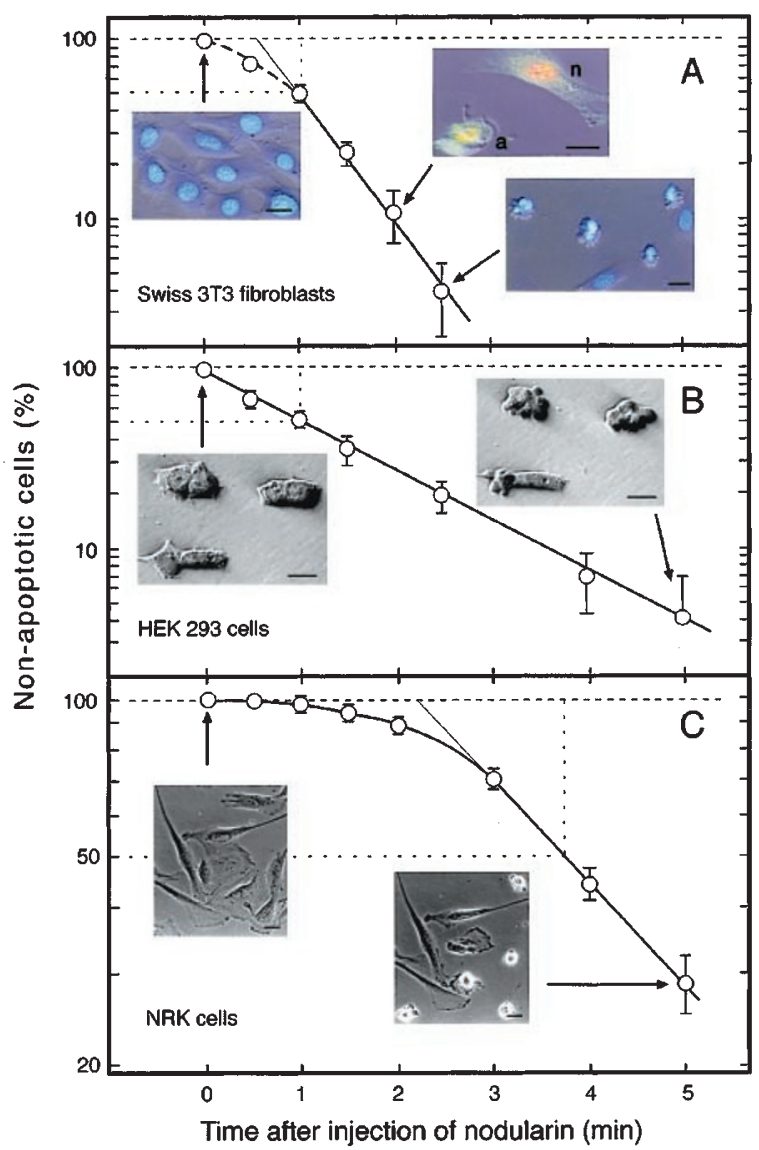

Figure 1 Rate of apoptosis induction after microinjection of nodularin. Swiss 3T3 fibroblasts (A), HEK 293 cells (B) or NRK fibroblasts (C) were injected with $250 \mu \mathrm{M}$ nodularin and scored for apoptosis by light microscopy. The dotted lines indicate the time when $50 \%$ of the cells had become apoptotic. Insets in (A): Combined Hoffman modulated contrast and fluorescence micrographs of cells before injection, $120 \mathrm{~s}$ after injection or $150 \mathrm{~s}$ after injection. Left and lower right insets show fixed cells whose DNA was stained with Hoechst 33342. Upper right inset shows unfixed cells whose phosphatidylserine was stained by externally applied FITC-conjugated Annexin-V. Both a necrotic ( $n$ ) and an apoptotic cell (a) are shown. The necrotic cell was deliberately produced by injection under high pressure and shows nuclear staining by propidium iodide, which did not penetrate into the apoptotic cell. Insets in (B): Hoffman modulated contrast images of HEK 293 cells before and $5 \mathrm{~min}$ after nodularin injection. Insets in (C): Phase contrast images of NRK cells before and 5 min after injection of nodularin. The error bars in the main panels represent S.E.M. values from at least three separate experiments. Further details are given in the Materials and Methods section. Bar, $10 \mu \mathrm{m}$ 
appeared to represent bona fide apoptosis. Both cytoplasmic and nuclear volume decreased by about $20 \%$ after 4 min incubation with a high concentration of microcystin (Figure 2B). At this stage no buds had been cleaved off the cell, so loss of cell fragments could not account for the cytoplasmic shrinkage. The cell buds defined by light microscopy were found to contain organelles like mitochondria by electron microscopy (Figure 2C). This distinguished them from 'toxic blebs', which have been described as a reversible phenomenon in cells exposed to toxic stress. ${ }^{32}$ Hypercondensation of chromatin (Figure 2C, lowest cell) occurred 80-120 min after surface budding and shrinkage (Figure 2D).

In order to probe for caspase involvement the oligopeptide Z-VAD.fmk was tested for ability to block nodularin-
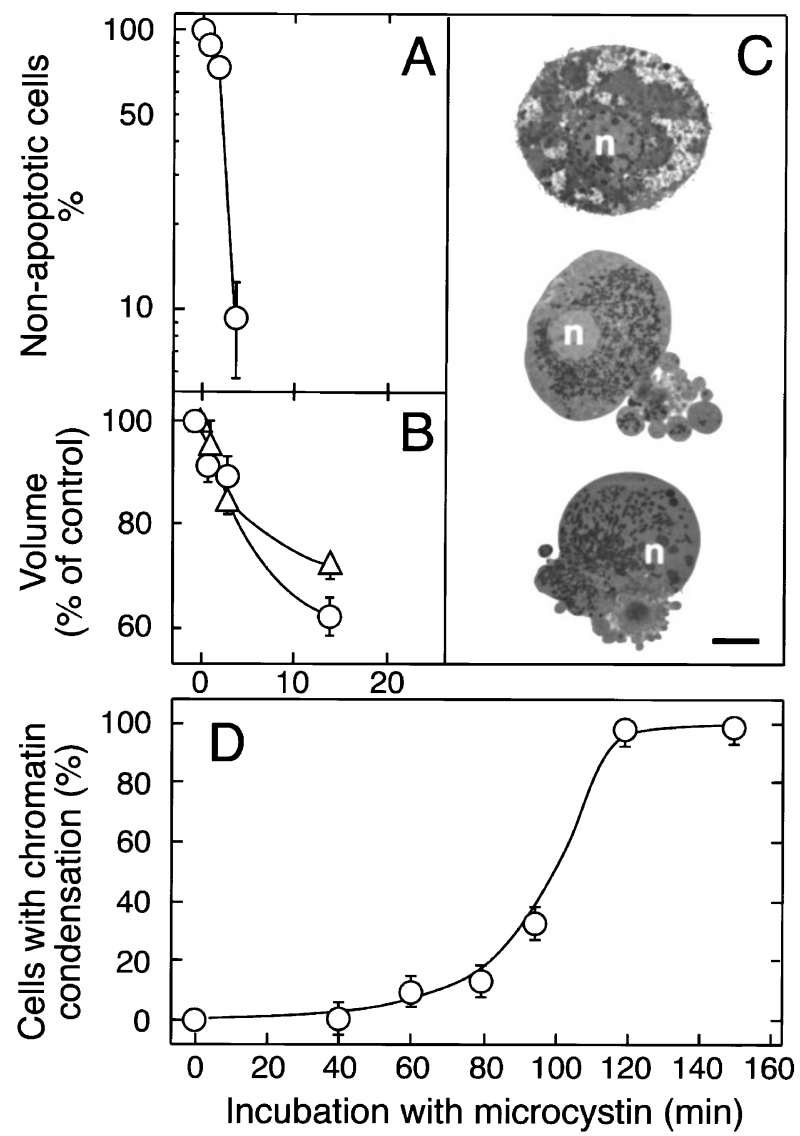

Figure 2 The sequential appearance of apoptotic features in freshly prepared rat hepatocytes exposed to a maximally effective medium concentration $(16 \mu \mathrm{M})$ of the phosphatase inhibitor microcystin-LR. (A) The progression of apoptosis, plotted as percentage of non-apoptotic cells (log. Scale) against time. (B) Morphometric evaluation of the relative cytoplasmic $(\bigcirc)$ and nuclear $(\triangle)$ volume of cells exposed to $16 \mu \mathrm{M}$ microcystin. (C) Electron micrographs of hepatocytes. The nucleus is indicated by $n$. Control cells (upper) had numerous microvilli and glycogen deposits. After $15 \mathrm{~min}$ with $16 \mu \mathrm{M}$ microcystin-LR (middle) most cells had lost their microvilli and glycogen, and the characteristic surface buds had begun to detach as apoptotic bodies. The mitochondria had become packed towards the pole with most buds. After $2 \mathrm{~h}$ (bottom) the nuclear chromatin had compacted. (D) Percentage of cells with chromatin condensation after challenge with $16 \mu \mathrm{M}$ microcystin. Error bars represent S.E.M. of 3-7 experiments. Details of culture conditions and procedure for morphological examination are given in the Materials and Methods section. Bar, $5 \mu \mathrm{m}$ induced hepatocyte apoptosis. Z-VAD.fmk is a broad inhibitor of caspases, including caspase-3. ${ }^{33}$ Hepatocytes preincubated with this peptide had strongly delayed apoptotic response to a maximally effective concentration $(5 \mu \mathrm{M})$ of nodularin (Figure $3 \mathrm{~A})$. Other caspase inhibitors at similar concentrations, like BOC.fmk and Z-IETD.fmk, were much less efficient blockers than Z-VAD.fmk (not shown). This indicated that the Z-VAD part and not the released fmk moiety was responsible for the effect of Z-VAD.fmk. Additional evidence of caspase activation was provided by demonstrating procaspase- 3 cleavage in hepatocytes exposed to nodularin. Immunoblotting showed increase of the $17 \mathrm{kDa}$ cleavage peptide, which is known to be the active caspase- 3 produced during proteolytic activation of

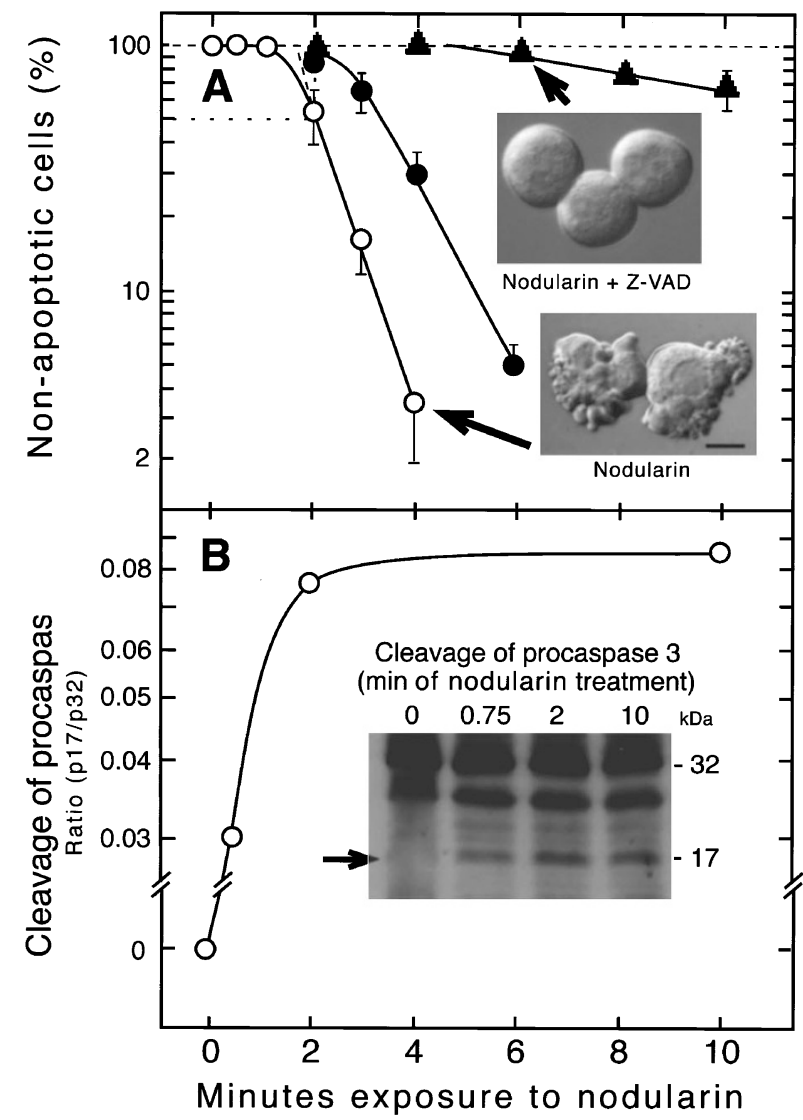

Figure 3 The rapid nodularin-induced hepatocyte apoptosis depends on caspase activity and is associated with cleavage of procaspase-3. (A) Freshly prepared rat hepatocytes in suspension were exposed to $5 \mu \mathrm{M}$ of the microcystin-like phosphatase inhibitor nodularin, which induced $50 \%$ apoptosis within $2 \mathrm{~min}(\mathrm{O})$. The nodularin induced apoptosis was moderately inhibited by preincubation with $50 \mu \mathrm{M}$ of the general caspase inhibitor ZVAD.fmk ( ) and strongly inhibited by $200 \mu \mathrm{M}$ Z-VAD.fmk (A). The insets in (A) show differential interference contrast micrographs of hepatocytes exposed to nodularin \pm Z-VAD.fmk. Error bars represent S.E.M. of 4-7 separate experiments. (B) Samples of hepatocytes, exposed to nodularin as explained for $(\mathbf{A})$, were centrifuged for $15 \mathrm{~s}$ and the pellet frozen in liquid nitrogen and processed for SDS electrophoresis and immuno-blotting to detect caspase-3 immuno-reactivity. The inset shows very rapid production of a $17 \mathrm{kDa}$ cleavage product of procaspase-3, and the main part of $(\mathbf{B})$ shows the time course of production of this $17 \mathrm{kDa}$ cleavage product relative to the parent p32 procaspase 
procaspase-3. The increase was maximal already after 2 min of nodularin exposure (Figure 3B). This is an unusually rapid cleavage of procaspase- 3 , which is considered to be a 'downstream' caspase, and has been shown to be activated at the earliest $10 \mathrm{~min}$ after Fasinduction. ${ }^{18}$

A more rigorous test of caspase-3 involvement in nodularin-induced death was provided by experiments using the human breast carcinoma cell line MCF-7. The wild-type variant of these cells is devoid of caspase$3,{ }^{1819,34}$ and should be sub-sensitive to nodularin injection if caspase-3 was involved in phosphatase inhibitor induced apoptosis. MCF-7 wild-type cells (data not shown) or cells transfected with empty vector underwent apoptosis much more slowly than any other cells injected with nodularin, and apoptosis was not inhibited by Z-VAD.fmk (Figure 4A). MCF-7 cells overexpressing caspase-3 regained sensitivity to nodularin and to Z-VAD.fmk (Figure 4B). This suggested an important role of caspase- 3 in the rapid death induced by nodularin. The slower, Z-VAD insensitive apoptosis induction in the caspase-3 deficient MCF-7 wild-type cells suggest the existence of an alternative, less efficient, apoptotic route which either relies on caspases resistant to Z-VAD.fmk or is completely caspase independent.

A number of experiments were conducted to probe if $\mathrm{Bcl}-2$ overexpression could protect against phosphatase inhibitor induced death. First, promyelocytic IPC-81 cells with stable overexpression of $\mathrm{Bcl}-2$ were tested. These cells were resistant to apoptosis induction by cAMP and up to $20 \mu \mathrm{M}$ daunorubicin (data not shown), but showed no significant delay in apoptotic response to injected nodularin, as compared to the wild-type IPC-81 cells (Figure 5). NRK cells and Swiss 3T3 fibroblasts were transiently transfected with bcl-2 expression vector, and tested for apoptosis development in response to microinjected nodularin and microinjected cytochrome $c$. No protection by $\mathrm{Bcl}-2$ was observed even if the nodularin concentration in the injection solution was lowered to a level $(50 \mu \mathrm{M})$ at which the rate of apoptosis induction was similar to that previously found after injection of cytochrome $c$, whose action was strongly inhibited in the Bcl-2 overexpressing cells. ${ }^{35}$ In conclusion, nodularin-induced apoptosis appeared not to be readily blocked by $\mathrm{Bcl}-2$.

\section{Inhibitors of phosphatase 1 and $2 A$ act synergistically to induce apoptosis}

Microcystin and nodularin inhibit phosphatases 1 and $2 \mathrm{~A}$ (PP1 and PP2A) with high potency. ${ }^{23,36}$ The polypeptides, inhibitor 1 and inhibitor 2 , are considered completely specific for PP1, ${ }^{37}$ and were tested in an attempt to know if selective inhibition of PP1 was sufficient to induce apoptosis. Neither peptide produced apoptosis when injected into primary rat hepatocytes in monolayer culture, while injection of an equimolar concentration $(50 \mu \mathrm{M})$ of microcystin-LR gave significant apoptosis (Figure 6A). There is no known completely specific inhibitor of PP2A, but okadaic acid is about 200-fold more potent as inhibitor of PP2A than of $\mathrm{PP} 1,{ }^{38}$ whereas tautomycin has preference for PP1. ${ }^{39} \mathrm{~A}$ clear synergism between okadaic acid and tautomycin was noted for induction of hepatocyte apoptosis (Figure 6B), suggesting that both PP2A and PP1 were involved in this type of death.

It was of interest to probe whether PP1 and PP2A were required also for the slower caspase 3-independent death of MCF-7 wild-type cells. A previous study by Favre et al. ${ }^{31}$ on intact MCF-7 cells showed that $1 \mu \mathrm{M}$ okadaic acid produced selective and near complete inhibition of PP2A, whereas $10 \mu \mathrm{M}$ tautomycin produce selective and near complete inhibition of PP1. When tested for apoptogenic activity against MCF-7 cells $1 \mu \mathrm{M}$ okadaic acid had only a slight effect and $10 \mu \mathrm{M}$ tautomycin had nearly no effect (not shown). This suggested that selective inhibition of either PP2A or PP1 was inefficient in producing apoptosis. When $1 \mu \mathrm{M}$ okadaic acid was combined with $10 \mu \mathrm{M}$ tautomycin a strong synergism was noted, suggesting involvement of

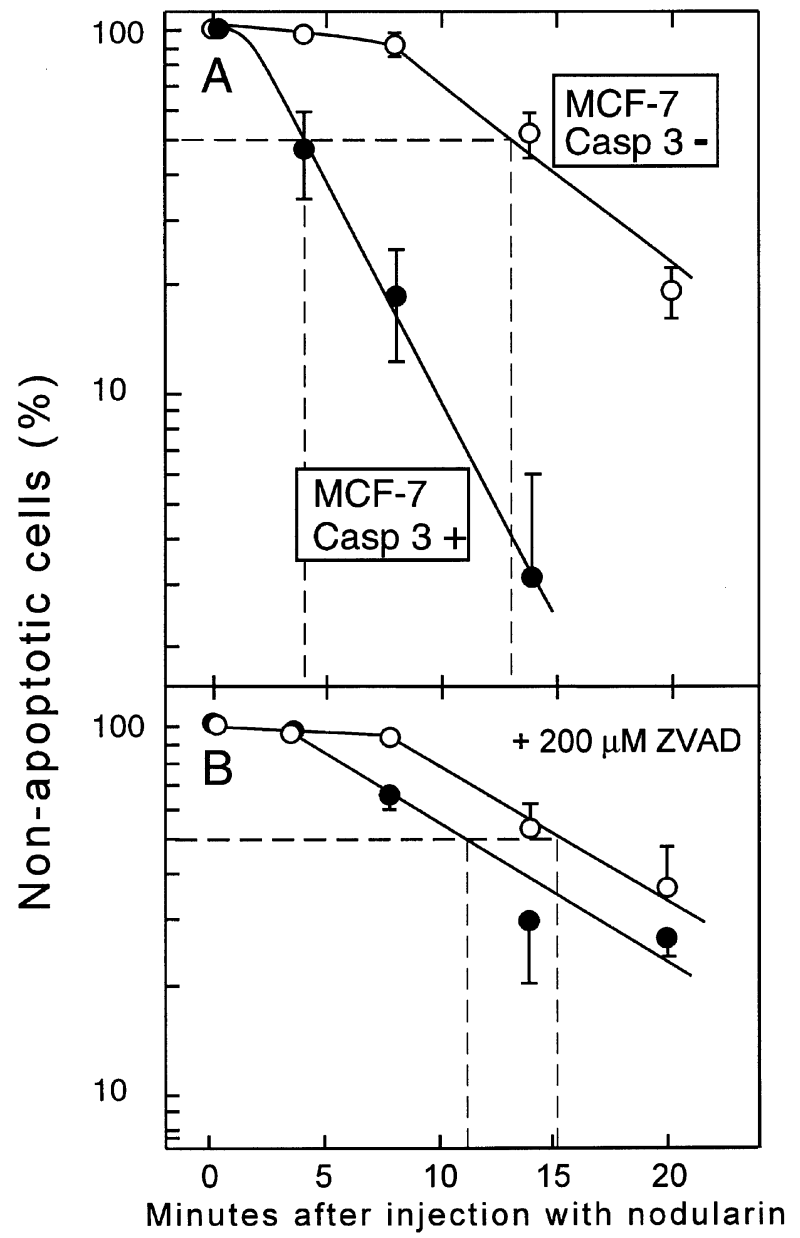

Figure 4 Caspase-3 is required for ultrarapid induction of apoptosis in MCF7 cells. Caspase- 3 deficient parental MCF-7 cells were stably transfected with caspase-3 (O) or the pcDNA-3 vector alone $(O)$ and injected with $500 \mu \mathrm{M}$ nodularin. (A and $\mathbf{B}$ ) show the time course of apoptosis development in the absence and presence, respectively, of ZVAD.fmk. In the mock-transfected wild-type cells the injection produced $50 \%$ apoptosis after about $15 \mathrm{~min}$ whether ZVAD,fmk was present or not. Similar results were obtained with wildtype cells not exposed to plasmid. The caspase- 3 expressing cells had both shorter lag before onset of apoptosis and a higher rate constant for apoptosis development. In the presence of ZVAD.fmk both the lag period and the rate approached those seen in wild-type cells. Error bars represent S.E.M. of 3-5 experiments 


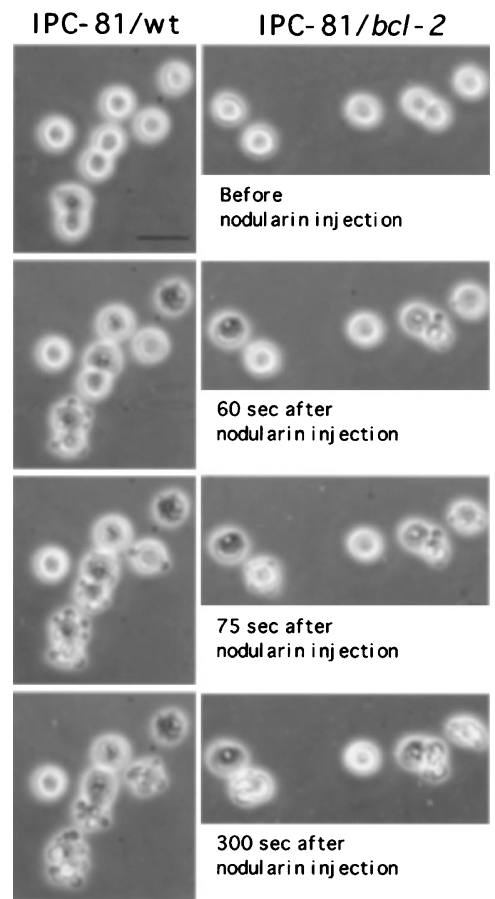

Figure $5 \mathrm{Bcl}-2$ overexpression does not protect against phosphatase inhibitor induced apoptosis. Rat leukemia IPC-81 cells, either wild-type (left column) or with stable overexpression of $\mathrm{Bcl}-2$ (right column) were immobilized on substratum and microinjected with $250 \mu \mathrm{M}$ nodularin. Even the $\mathrm{Bcl}-2$ expressing cells developed apoptotic morphology within 1-5 min after injection. Error bars represent S.E.M. of 3-4 experiments. Bar, $10 \mu \mathrm{m}$

both PP1 and PP2A also for apoptosis induction in wildtype MCF-7 cells.

\section{Apoptosis is preceded by increased protein phosphorylation}

The ability of nodularin and microcystin to produce physical evidence of apoptosis (cell shrinkage and cytoskeletal rearrangements) within 2 min (Figures $1-3,5$ ) raised the question of whether phosphatase inhibition and resulting perturbation of protein phosphorylation could act fast enough to explain apoptosis development. To answer this question hepatocytes were preincubated with ${ }^{32} \mathrm{P}_{\mathrm{i}}$ to label the terminal phosphate of ATP, ${ }^{40}$ and then exposed to nodularin. After 2 and 5 min of incubation the intracellular phosphorylation was stopped abruptly using trichloracetic acid, and the precipitated protein dissolved and separated by 2-dimensional gel electrophoresis. Autoradiograms of such gels showed that several proteins had increased phosphorylation intensity already after $2 \mathrm{~min}$ of incubation with nodularin (Figure $7 A, B$; spots $a-g$ ). One group of phosphoproteins (labeled MLC in Figure 7A) showing acid shift upon incubation with nodularin (Figure 7B,C) was identified by Western-blot as myosin light chain (Figure $7 \mathrm{G}-\mathrm{J}$ ). The intensity of the spots increased from 2 to 5 min of incubation and a few novel spots $(\mathrm{h}, \mathrm{i})$ were detected as well (Figure 7C). The finding of significant protein phosphorylation after only 2 min of incubation with nodularin supported the view that protein
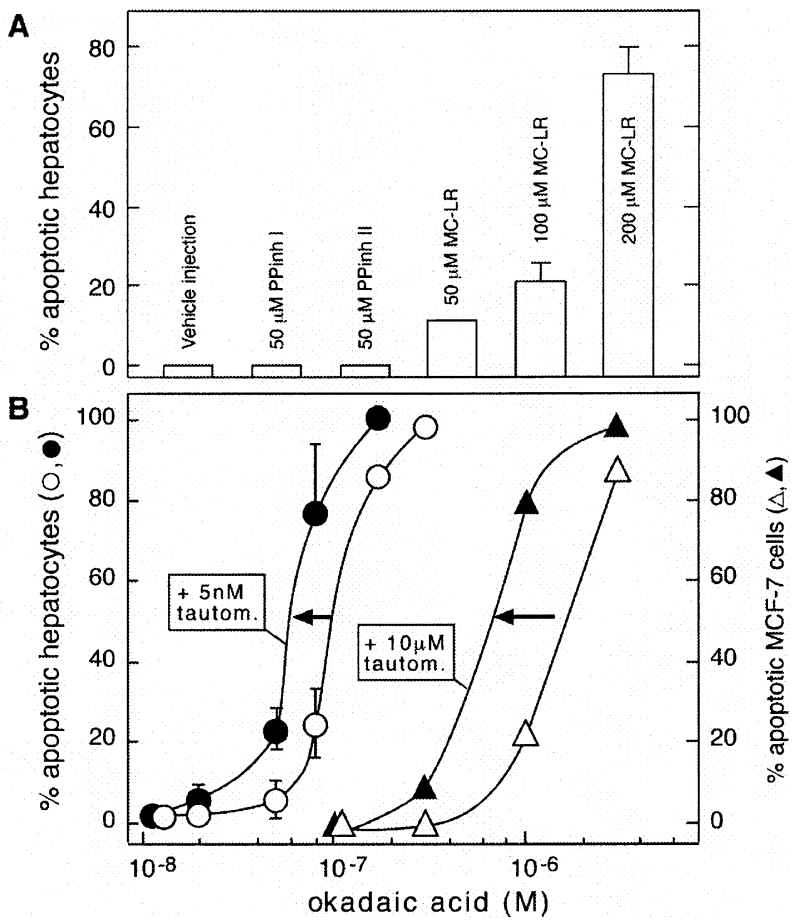

Figure 6 Synergistic induction of apoptosis by inhibitors of protein phosphatase 2A and 1. (A) Microinjection of specific peptide inhibitors of protein phosphatase 1 (PPinhl or PPinhll) at $50 \mu \mathrm{M}$ did not induce apoptosis in primary hepatocytes. Microinjection of $50 \mu \mathrm{M}$ of microcystin-LR, which is an equipotent inhibitor of phosphatases 1 and $2 \mathrm{~A}$, induced significant apoptosis. Fifty per cent apoptosis was achieved between 100 and $200 \mu \mathrm{M}$ microcystin. Apoptotic cells were scored $20 \mathrm{~min}$ after injection. Error bars represent S.E.M. of 3-4 experiments. (B) The concentration-dependence of okadaic acid as inducer of apoptosis in hepatocytes in suspension $(O)$ and wild-type MCF-7 cells in monolayer culture $(\triangle)$. Okadaic acid preferentially inhibits protein phosphatase $2 \mathrm{~A}$, and became more potent as apoptosis inducer when combined $(\boldsymbol{\Theta}, \mathbf{\Lambda})$ with concentrations of the protein phosphatase 1 preferring inhibitor tautomycin which by themselves failed to produce apoptosis. Hepatocytes were fixed after $20 \mathrm{~min}$ of incubation, and apoptosis determined by evaluating the cell surface morphology. Apoptosis in MCF-7 cells was determined after $2 \mathrm{~h}$ of incubation by evaluating nuclear morphology (hypercondensation of chromatin) in Hoechst 33342 stained cells

phosphorylation might be the prime mediator of nodularininduced apoptosis. An alternative explanation was that caspase activity had activated a protein kinase and thereby enhanced phosphorylation. This was tested in hepatocytes treated with Z-VAD.fmk under conditions delaying the onset of apoptosis to $5 \mathrm{~min}$ after nodularin treatment had started (Figure 3A). Significant hyperphosphorylation was observed after 2 min and considerably increased phosphorylation after 5 min even in cells pretreated with Z-VAD.fmk (Figure 7D-F). Furthermore, a full acidic shift of myosin light chain was observed in such cells (Figure $7 \mathrm{~J}$ ). This argued that nodularininduced protein phosphorylation was not the result of Z-VADinhibitable caspase activity.

\section{Discussion}

Inhibition of phosphatases may be a particularly efficient way of harming cells, since a number of toxins from diverse microorganisms and of different chemical structure target the highly conserved protein phosphatases $2 \mathrm{~A}$ and $1 .{ }^{24,25,39,41-43}$ The 

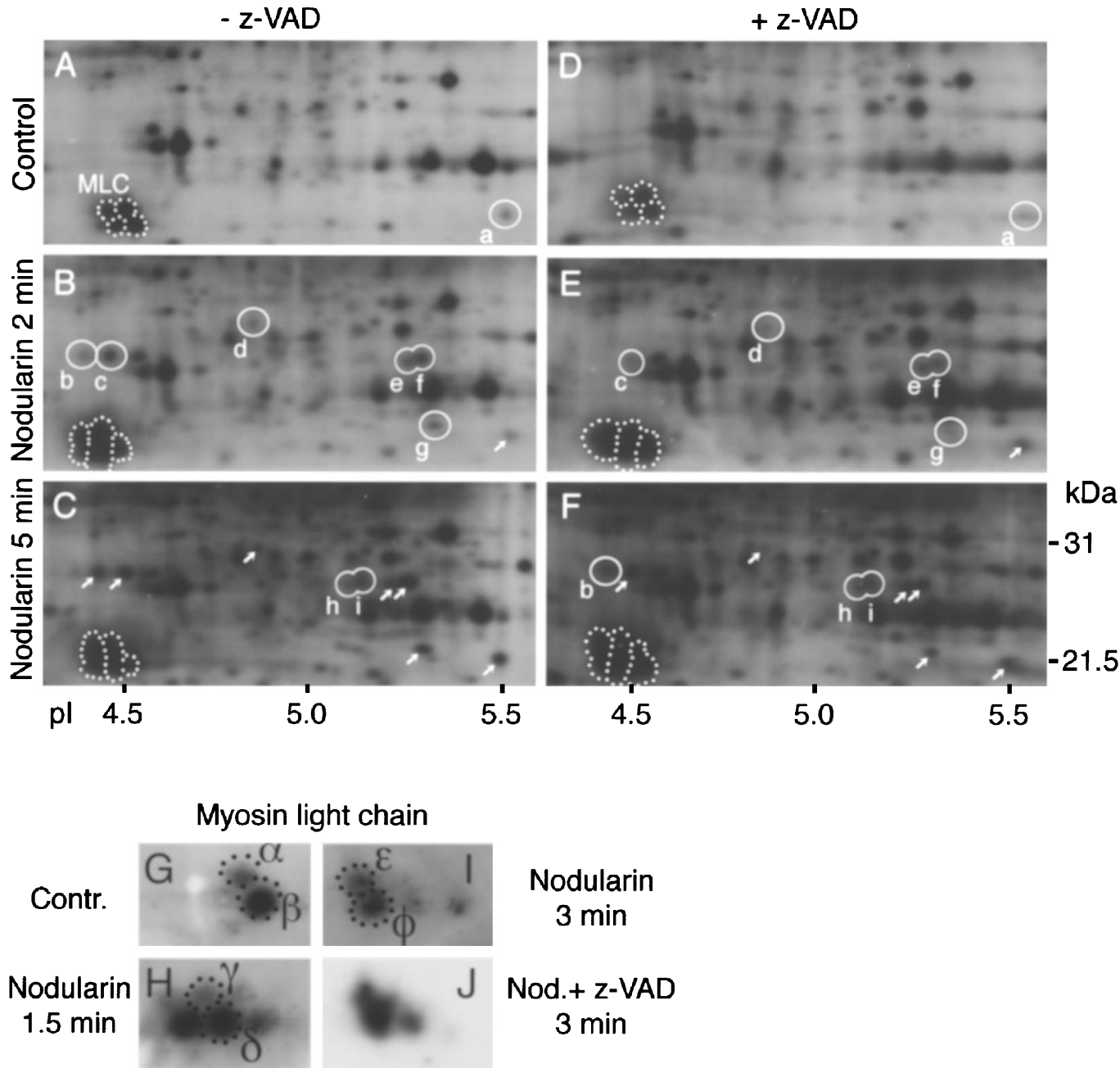

Figure 7 Protein phosphorylation in hepatocytes treated with nodularin. (A-F) Autoradiograms after 2-dimensional electrophoresis of extracts from hepatocytes in suspension prelabeled with ${ }^{32} \mathrm{P}_{\mathrm{i}}$ for $35 \mathrm{~min}$, and treated for 2 min with vehicle alone (A,D), or with $5 \mu \mathrm{M}$ nodularin for 2 min $(\mathbf{B}, \mathbf{E})$ or 5 min $(\mathbf{C}, \mathbf{F})$. For (D-F) the cells had been exposed to $200 \mu \mathrm{M}$ ZVAD.fmk from 30 min before nodularin action. Spot a and myosin light chain (MLC) were phosphorylated already in control cells $(A, D)$. For spot a increased phosphorylation was noted in response to nodularin and for MLC an increased acidic shift indicative of phosphorylation of additional sites. (B,C,E,F). Spots b-i appeared in response to nodularin. Note that all spots (a-i) were present even in ZVAD-treated cells (F). (G-J) Show 2-dimensional Western blots of MLC from control cells $(\mathbf{G})$ and cells treated with $5 \mu \mathrm{M}$ of the phosphatase inhibitor nodularin alone for $1.5(\mathbf{H})$ or $3(\mathbf{I})$ min. The treatment led to decreased abundance of the basic pair of MLC spots $(\alpha, \beta)$, increased abundance of the slightly more acidic pair of spots $(\chi, \delta)$ and the appearance of a novel, even more acidic pair of spots $(\varepsilon, \phi)$. (J) Represents cells exposed to $200 \mu \mathrm{M}$ ZVAD-fmk before incubation (3 min) with nodularin

apoptogenic effect of the hepatotoxic phosphatase inhibitors microcystin and nodularin seemed to be general, as it was produced by micro injection in all our tested cell lines. We and others have previously shown that cell-permeant protein phosphatase inhibitors like okadaic acid are general inducers of apoptosis and act independently of new protein synthesis. $^{27-29}$ This implies that most, if not all, cells have the machinery required to undergo apoptosis in response to phosphatase inhibitors. The only other agent which is so generally apoptogenic as the phosphatase inhibitors appears to be staurosporine. ${ }^{43}$ The primary apoptosis-mediating target of this broad kinase inhibitor is unknown, ${ }^{45}$ but its action is blocked by $\mathrm{Bcl}-2^{16}$ and involves mitochondrial leakage of cytochrome $c{ }^{46}$ The phosphatase inhibitor induced death was distinct from staurosporine induced death, since it was not counteracted by overexpression of $\mathrm{Bcl}-2$.
The most striking finding of the present study was the rapidity with which phosphatase inhibitors could induce a complete apoptotic phenotype, including cell surface budding, cytoplasmic and nuclear shrinkage, externalization of phosphatidylserine, and procaspase cleavage. In most cases there is a lag of $30 \mathrm{~min}$ or more between application of a physiological apoptogenic stimulus and the first morphological signs of apoptosis. Examples hereof are the Fas/Apo-1/CD95-system ${ }^{47}$ (and references therein), glucocorticoid-induced thymocyte apoptosis, ${ }^{48}$ growth factor (e.g. IL-3) withdrawal, ${ }^{49}$ and cAMP-induced apoptosis of the presently studied IPC-81 leukemia cells. ${ }^{50}$ On the basis of the results presented, it seems reasonable to suggest that phosphatase inhibitors have evolved as rapidly lethal toxins by acquiring ability to short-cut normal apoptotic pathways, presumably acting close to the execution 
machinery. Short-cutting of death pathways acting through release of mitochondrial cytochrome $c$ can be done by direct microinjection of cytochrome $c$ into cells. ${ }^{17,35}$ Even injection of maximally efficient concentrations of cytochrome $c$ acted five to ten times more slowly ${ }^{17}$ than injected nodularin in inducing death of the presently studied cell lines. T-cell mediated cytotoxicity may be the best studied example of short-cutting of normal death pathways, and represents to our knowledge the most rapid apoptosis induction described before the present report. The target cell can undergo a mixture of necrotic and apoptotic changes as early as 3-10 min after close contact with a killer cell. ${ }^{51,52}$ The death mechanism appears to be perforin-facilitated delivery of caspase-activating granzymes to the target cell. ${ }^{53}$ On this basis it is not surprising that granzyme/perforin action is rapid, but all the more puzzling that phosphatase inhibitors acted even more rapidly.

Another striking finding of the present study was the much slower action of nodularin in cells devoid of caspase3 as compared to the same cell type expressing caspase-3. Although caspase-3 cleavage was demonstrated very early in the nodularin treated hepatocytes it is possible that nodularin could induce reversible activation of procaspase3 without cleavage, as well. It has recently been demonstrated that procaspase-3 can be reversibly activated by a peptide in the caspase-3 expressing MCF-7 cells used in the present study. ${ }^{54}$

A major challenge will be to define the steps between nodularin addition to the cells and caspase- 3 activation. The fact that a number of chemically distinct PP2A/PP1 targeting compounds induced apoptosis strongly suggests that protein phosphatase inhibition and not a nonspecific effect is the first step in nodularin- and microcystin-induced apoptosis. The present study suggests that inhibition of both phosphatases 1 and $2 \mathrm{~A}$ was required to induce apoptosis. The overlapping substrate specificity of the two phosphatases $^{55,56}$ may account for this dual requirement, since one protein phosphatase would substitute if the other one was inhibited. The concept that inhibition of dephosphorylation was instrumental in apoptosis induction was supported by the demonstration of significantly increased intracellular protein phosphorylation already after $2 \mathrm{~min}$ of nodularin treatment. This phosphorylation was apparently not the result of caspase dependent, apoptosis-associated activation of protein kinases, ${ }^{57}$ since it was observed in cells in which apoptosis was repressed by the caspase inhibitor ZVAD.fmk. The link between protein hyperphosphorylation and caspase activation remains to be elucidated.

\section{Materials and Methods}

\section{Materials}

Nodularin was from LC Services (Woburn, MA, USA). Microcystin-LR, tautomycin, calyculin $A$ and bisbenzimide $(\mathrm{H} 33342)$ were obtained from Calbiochem (La Jolla, CA, USA). Z-VAD.fmk was from Bachem Feinchemikalien AG (Bubendorf, Switzerland) and Z-IETD.fmk from
Enzyme Systems Products (Livermore, CA, USA). FITC-conjugated Annexin $V$ was from Nexins Research B.V. (Hoeven, The Netherlands). Purified inhibitor-1 and inhibitor-2 were generously supplied by Philip Cohen (University of Dundee, UK). The antibodies against caspase-3 were kindly donated by Donald W Nicholson (Merck Frosst Center for Therapeutic Research, Quebec, Canada). Goat anti-mouse antibody was from Pierce (Rockford, IL, USA) anti-myosin light chain antibody (M4401) and the ammonium salt of okadaic acid were from Sigma (St. Louis, MO, USA). Horseradish peroxidase-conjugated sheep anti-mouse antibody (NA931) and $\left[{ }^{32} \mathrm{P}\right]$ orthophosphate $(10 \mathrm{mCi} / \mathrm{ml})$ were from Amersham (Little Chalfont, UK). Pharmalyte and linear immobilized $\mathrm{pH}$ 4.0-7.0 gradients were from Pharmacia Biotechnology (Uppsala, Sweden).

\section{Cells}

Hepatocytes were isolated from male Wistar rats $(120-200 \mathrm{~g})$ by in vitro collagenase perfusion and either cultured in monolayers on collagen as previously described ${ }^{58}$ or kept in suspension. For the latter the hepatocytes $\left(1.2 \times 10^{6}\right.$ cells $\left./ \mathrm{ml}\right)$ were incubated at $37^{\circ} \mathrm{C}$ in capped vials with gyratory shaking ( $175 \mathrm{cycles} / \mathrm{min})$. The medium was pre-gassed $\left(5 \% \mathrm{CO}_{2} / 95 \% \mathrm{O}_{2}\right)$ and consisted of $10 \mathrm{mM} \mathrm{HEPES}(\mathrm{pH}$ 7.4), $120 \mathrm{mM} \mathrm{NaCl}, 5.3 \mathrm{mM} \mathrm{KCl}, 0.01 \mathrm{mM} \mathrm{KH}_{2} \mathrm{PO}_{4}, 1.2 \mathrm{mM} \mathrm{MgSO}_{4}$, $1.0 \mathrm{mM} \mathrm{CaCl}_{2}, 5 \mathrm{mM}$ lactate, and $5 \mathrm{mM}$ pyruvate.

Human embryo kidney HEK 293 cells and normal rat kidney NRK cells were grown in Dulbecco's modification of Eagle's minimal essential medium (DMEM) with $10 \%$ fetal calf serum, $50 \mathrm{U} / \mathrm{ml}$ of penicillin and $50 \mu \mathrm{g} / \mathrm{ml}$ streptomycin. Swiss $3 \mathrm{~T} 3$ mouse embryo fibroblasts were grown in DMEM and RPMI 1640 (50/50 v/v), and supplemented with serum and antibiotics as described above.

Breast carcinoma cell line MCF-7 stably transfected with either caspase-3 or empty vector ${ }^{56}$ were kindly provided by Dr. S Lord and $\mathrm{N}$ Henriques (Birmingham, UK). MCF-7 cell lines were cultured in RPMI supplemented with $2 \mathrm{mM}$ glutamine and $10 \%$ fetal calf serum. Clones were selected for in media containing $500 \mu \mathrm{g} / \mathrm{ml} \mathrm{G} 418$.

Rat promyelocytic IPC-81 leukemia cells were cultured in DMEM with $7 \%$ horse serum. IPC-81 cells with stable overexpression of $\mathrm{Bcl}-2$ (IPC-81/bcl2) was a kind gift from Dr. Michel Lanotte (Institut d'Hématologie, Paris, France). Selection for $b c l-2$ stable cells was done by culturing with puromycin at $0.5 \mu \mathrm{g} / \mathrm{ml}$ for 5 days every 30 days. No viable cells were found in cultures not transfected with $b c l-2$.

Cells were transfected with $b c l-2$ as previously described. ${ }^{17}$ Some dishes were co-transfected with a lacZ-containing plasmid for estimation of transfection efficiency using a fluorescent $\beta$-galactosidase substrate. ${ }^{59}$

The caspase inhibitor Z-VAD.fmk was added to the cell medium 20-30 $\mathrm{min}$ before the cells were exposed to phosphatase inhibitors.

\section{Microinjection}

Microinjection was performed using an Eppendorf 5171 micromanipulator mounted on a Nikon Diaphot 300 inverted microscope. Microcapillaries (type BF100-10, 1.00/0.78) and puller (Model P-87) were from Sutter Instrument Co. (Novato, CA, USA). Optimal injections were obtained with capillary pipettes of which the tip diameter was less than $0.3 \mu \mathrm{m}$. Pipettes were loaded by retrograde filling. The injected volume was estimated as previously shown ${ }^{60}$ to be close to $2 \%$ of the cellular volume, corresponding to 50 -fold dilution of injected material. For each experimental parameter approximately 150 cells were injected. Phosphatase inhibitors were delivered in a buffer with $5 \%$ DMSO, but otherwise approaching the intracellular composition of 
electrolytes. ${ }^{61}$ Inhibitor-1 was preincubated with $5 \mu \mathrm{M}$ of the catalytic subunit of CAMP-dependent protein kinase and $\mathrm{Mg}^{2+}$ /ATP prior to microinjection to ensure full activation of the inhibitor. ${ }^{62}$ Additionally, cells injected with inhibitor-1 were sometimes exposed to $200 \mu \mathrm{M}$ of CAMP analog (8-chlorothio-CAMP) to ensure continued activation of endogenous cAMP-dependent protein kinase. Control cells were injected with the relevant vehicles. In no case did injection of vehicle alone lead to significant apoptosis.

All injected cell types were cultured in $9.8 \mathrm{~cm}^{2}$ dishes with grid patterns forming $4-\mathrm{mm}^{2}$ squares. HEK 293, NRK, Swiss 3T3, and MCF-7 cells ( 10000 cells $\left./ \mathrm{cm}^{2}\right)$ were injected $24-48 \mathrm{~h}$ after seeding. Hepatocytes $\left(30000\right.$ cells $\left./ \mathrm{cm}^{2}\right)$ were injected after $44-56 \mathrm{~h}$ of culture. IPC-81 and IPC-81-bcl-2 cells to be injected were seeded at $30000 \mathrm{cells} / \mathrm{cm}^{2}$ in dishes precoated with fibronectin $\left(1 \mu \mathrm{g} / \mathrm{cm}^{2}\right)$, and treated with $100 \mathrm{nM}$ of the phorbol ester TPA to further improve cell attachment (for details see Vintermyr et al. ${ }^{63}$ )

\section{Scoring of apoptotic morphology}

For routine assessment of apoptosis, the cell morphology was evaluated by inverted phase microscopy using phase- and Hoffman modulated-optics. Apoptotic cells were easily discriminated from nonapoptotic (both normal and necrotic) cells by the appearance of multiple surface buds. For evaluation of the chromatin condensation, cells fixed in $0.1 \mathrm{M} \mathrm{Na-cacodylate} \mathrm{buffer} \mathrm{(} \mathrm{pH} 7.4$ ) with $1.5 \%$ glutaraldehyde were stained with $1 \mu \mathrm{g} / \mathrm{ml}$ of the DNA-specific dye Hoechst 33342 (bisbenzimide). When surface features were to be illustrated in bisbenzimide-stained cells, they were double-exposed using both fluorescence and differential interference contrast microscopy. The progress of apoptosis in a cell population was evaluated quantitatively by plotting semilogarithmically the fraction of cells remaining non-apoptotic against time. In most cases this plot became rectilinear after a lag period and its slope gave the rate constant for the transition from normal to apoptotic phenotype.

For transmission electron microscopy cell aliquots were fixed in 10 -fold excess of $1.5 \%$ glutaraldehyde buffered with $0.1 \mathrm{M} \mathrm{Na}$ cacodylate $(\mathrm{pH} 7.4)$ and processed as described previously. ${ }^{27}$ Estimation of the nuclear and cell volume was determined on semithin toluidine blue-stained sections using a semiautomatic image analyzer and a primary magnification of $630 \times$. Phosphatidylserine was visualized by incubating cells with FITC-conjugated Annexin IV (according to ${ }^{64}$ ) Since annexin $V$ can bind to phosphatidylserine on the internal side of the plasma membrane if the plasma membrane is not intact the cells were counterstained with $5 \mu \mathrm{g} / \mathrm{ml}$ propidium iodide to detect membrane leaks. The cells were scored using a filter set for FITC-staining with a long-pass filter for the simultaneous detection of propidium iodide. Only propidium iodine-negative annexin V-staining cells were considered certain to have externalized phosphatidylserine.

\section{Labeling of cellular phosphoproteins and 2- dimensional gel electrophoresis}

Suspension cultures of hepatocytes were preincubated with ${ }^{32} \mathrm{P}_{\mathrm{i}}$ $(1000 \mu \mathrm{Ci} / \mathrm{ml})$ for $35 \mathrm{~min}$ before the addition of nodularin. The incubations were terminated by adding a tenfold excess of ice-cold $8 \%$ aqueous trichloroacetic acid. Samples were spun $(15000 \times g$ for $15 \mathrm{~min}$ ) and washed in $5 \%$ aqueous trichloroacetic acid. Cell pellets were lyzed in $100 \mu \mathrm{l}$ of a solution containing $9.8 \mathrm{M}$ urea, $100 \mathrm{mM}$ DTE (1,4-dithioerythritol), $1.5 \% \mathrm{v} / \mathrm{v}$ Pharmalyte $\mathrm{pH} 3.5-10,0.5 \% \mathrm{v} / \mathrm{v}$ Pharmalyte $\mathrm{pH}$ 5-6, 4\% w/v CHAPS (3-[(3-cholamidopropyl)dimethylammonio]-1-propanesulfonate) and $0.2 \% \mathrm{w} / \mathrm{v}$ SDS. The 2-dimensional sample separation was as described in, ${ }^{65}$ using a linear immobilized $\mathrm{pH} 4.0-7.0$ gradient for the first dimension and $13.75 \%$ SDS-PAGE for the second dimension.

\section{Western blot analysis}

For immunodetection (Western blot) of myosin light chain, proteins were transferred from 2-dimensional gels by electroblotting $(70 \mathrm{~h}$ at $15 \mathrm{~V}, 4^{\circ} \mathrm{C}$ ) onto nitrocellulose membranes. Blots were incubated with anti-myosin light chain antibody followed by horseradish peroxidaseconjugated sheep anti-mouse antibody. The blots were developed using ECL (Pharmacia, Uppsala, Sweden).

For immunodetection of caspase-3, hepatocytes $\left(10^{6}\right)$ treated with apoptogen were rapidly centrifuged, and the pellet frozen in liquid nitrogen. The pellet was resuspended in Laemmli buffer supplemented with a cocktail of protease inhibitors (1 mM PMSF, $1 \mathrm{mM} \mathrm{1,10-}$ phenantroline, $20 \mu \mathrm{g} / \mathrm{ml}$ leupeptin, $5 \mu \mathrm{g} / \mathrm{ml}$ pepstatin and $20 \mu \mathrm{g} / \mathrm{ml}$ calpain inhibitor I). After boiling for $4 \mathrm{~min}$, the polypeptides were resolved at $130 \mathrm{~V}$ on $12 \%$ SDS polyacrylamide gels. The gels were transblotted onto nitrocellulose membranes $(0.2 \mu \mathrm{m})$ for $2 \mathrm{~h}$ at $100 \mathrm{~V}$. The membranes were blocked overnight in a buffer $(50 \mathrm{mM}$ Tris, $\mathrm{pH}$ $7.5,500 \mathrm{mM} \mathrm{NaCl}$ ) containing $1 \%$ bovine serum albumin and $5 \%$ nonfat milk powder. They were then probed with primary antibodies against $\mathrm{p} 17$ in blocking solution without milk, followed by $1 \mathrm{~h}$ with secondary $\lg G(1: 10000$ in an identical solution), and then visualized by ECL according to the manufacturer. The ratio between the cleavage product ( $\mathrm{p} 17)$ and procaspase-3 (p32) was determined by computerassisted densitometric evaluation.

\section{Acknowledgements}

We are indebted to Nina Lied Larsen, Erna Finsås, and Berit Hausvik for expert technical assistance. The work was funded by The Norwegian Cancer Society, the Norwegian Research Council, the Marine Science and Technology (MAST III) Program of the European Commission, and the Novo Nordic Foundation.

\section{References}

1. Kerr JF, Wyllie AH and Currie AR (1972) Apoptosis: a basic biological phenomenon with wide-ranging implications in tissue kinetics. Br. J. Cancer 26 : $239-257$

2. Wyllie AH, Kerr JF and Currie AR (1980) Cell death: the significance of apoptosis. Int. Rev. Cytol. 68: 251-306

3. Houge $\mathrm{G}$ and Døskeland SO (1996) Divergence towards a dead end? Cleavage of the divergent domains of ribosomal RNA in apoptosis. Experientia 52: 963967

4. Martin SJ, Reutelingsperger CP, McGahon AJ, Rader JA, van Schie RC, LaFace DM and Green DR (1995) Early redistribution of plasma membrane phosphatidylserine is a general feature of apoptosis regardless of the initiating stimulus: inhibition by overexpression of Bcl-2 and Abl. J. Exp. Med. 182: 15451556

5. Fadok VA, Voelker DR, Campbell PA, Cohen JJ, Bratton DL and Henson PM (1992) Exposure of phosphatidylserine on the surface of apoptotic lymphocytes triggers specific recognition and removal by macrophages. J. Immunol. 148: 2207-2216

6. Van de Craen M, Van Loo G, Pype S, Van Criekinge W, Van den brande I, Molemans F, Fiers W, Declercq W and Vandenabeele P (1998) Identification of a new caspase homologue: caspase-14. Cell Death Differ. 5: 838-846

7. Thornberry NA and Lazebnik Y (1998) Caspases: enemies within. Science 281: $1312-1316$

8. Muzio M, Stockwell BR, Stennicke HR, Salvesen GS and Dixit VM (1998) An induced proximity model for caspase-8 activation. J. Biol. Chem. 273: 2926 2930 
9. Butt JA, Harvey NL, Parasivam G and Kumar S (1998) Dimerization and autoprocessing of the Nedd2 (caspase-2) precursor requires both the prodomain and the carboxyl-terminal regions. J. Biol. Chem. 273: 6763-6768

10. Nicholson DW and Thornberry NA (1997) Caspases: killer proteases. Trends Biochem. Sci. 22: 299-306

11. Zhivotovsky B, Burgess DH, Vanags DM and Orrenius S (1997) Involvement of cellular proteolytic machinery in apoptosis. Biochem. Biophys. Res. Commun. 230: $481-488$

12. Villa P, Kaufmann SH and Earnshaw WC (1997) Caspases and caspase inhibitors. Trends Biochem. Sci. 22: 388-393

13. Luo X, Budihardjo I, Zou H, SlaughterC and Wang X (1998) Bid, a Bcl2 interacting protein, mediates cytochrome $c$ release from mitochondria in response to activation of cell surface receptors. Cell 94: 481-490

14. Adams JM and Cory S (1998) The Bcl-2 protein family: arbiters of cell survival. Science 281: 1322-1326

15. Kluck RM, Bossy-Wetzel E, Green DR and Newmeyer DD (1997) The release of cytochrome c from mitochondria: A primary site for $\mathrm{Bcl}-2$ regulation of apoptosis. Science 275: 1132-1136

16. Yang J, Liu X, Bhalla K, Kim CN, Ibrado AM, Cai J, Peng T-I, Jones DP and Wang $X$ (1997) Prevention of apoptosis by Bcl-2: Release of cytochrome $\mathrm{c}$ from mitochondria blocked. Science 275: 1129-1132

17. Brustugun OT, Fladmark KE, Døskeland SO, Orrenius $S$ and Zhivotovsky $B$ (1998) Apoptosis induced by the microinjection of cytochrome $C$ is caspasedependent and is inhibited by Bcl-2. Cell Death Differ. 5: 660-668

18. Scaffidi C, Fulda S, Srinivasan A, Friese C, Li F, Tomaselli KJ, Debatin K-M, Krammer PH and Peter ME (1998) Two CD95 (APO-1/Fas) signalling pathways. EMBO J. 17: 1675-1687

19. LiF, Srinivasan A, Wang Y, Armstrong RC, Tomaselli KJ and Fritz LC (1997) Cellspecific induction of apoptosis by microinjection of cytochrome $\mathrm{C}$. Bcl-xl has activity independent of cytochrome c release. J. Biol. Chem. 272: 30299 - 30305

20. Anderson $P$ (1997) Kinase cascades regulating entry into apoptosis. Microbiol. Mol. Biol. Rev. 61: 33-46

21. Martins LM, Kottke TJ, Kaufmann SH and Earnshaw WC (1998) Phosphorylated forms of activated caspases are present in cytosol from HL-60 cells during etoposide-induced apoptosis. Blood 92: 3042-3049

22. Gjertsen BT and Døskeland SO (1995) Protein phosphorylation in apoptosis. Biochim. Biophys. Acta 1269: 187-199

23. Holmes CFB and Boland MP (1993) Inhibitors of protein phosphatases-1 and $2 \mathrm{~A}$; two of the major serine/threonine protein phosphatases involved in cellular regulation. Curr. Opin. In Struct. Biol. 3: 934-943

24. Honkanen RE, Dukelow M, Zwiller J, Moore RE, Khatra BS and Boynton AL (1991) Cyanobacterial nodularin is a potent inhibitor of type 1 and type $2 A$ protein phosphatases. Mol. Pharmacol. 40: 577-583

25. Cohen P, Holmes CF and Tsukitani Y (1990) Okadaic acid: a new probe for the study of cellular regulation. Trends Biochem. Sci. 15: 98-102

26. Fladmark KE, Serres MH, Yasumoto T, Larsen NL, Aune T and Døskeland SO (1998) Sensitive detection of apoptogenic toxins in suspension cultures of rat and salmon hepatocytes. Toxicon 36: 1101-1114

27. Bøe R, Gjertsen B, Vintermyr O, Houge G, Lanotte M and Døskeland S (1991) The protein phosphatase inhibitor okadaic acid induces morphological changes typical of apoptosis in mammalian cells. Exp. Cell Res. 195: 237-246

28. Kiguchi K, Glesne D, Chubb CH, Fujiki H and Huberman E (1994) Differential induction of apoptosis in human breast tumor cells by okadaic acid and related inhibitors of protein phosphatases 1 and 2A. Cell Growth Differ. 5: 995-1004

29. Yan Y, Shay JW, Wright WE and Mumby MC (1997) Inhibition of protein phosphatase activity induces p53-dependent apoptosis in the absence of p53 transactivation. J. Biol. Chem. 272: 15220-15226

30. Runnegar MT, Gerdes RG and Falconer IR (1991) The uptake of the cyanobacterial hepatotoxin microcystin by isolated rat hepatocytes. Toxicon. 29: $43-51$

31. Favre B, Turowski P and Hemmings BA (1997) Differential inhibition and posttranslational modification of protein phosphatase 1 and 2A in MCF7 cells treated with calyculin-A, okadaic acid, and tautomycin. J. Biol. Chem. 272: $13856-13863$

32. Majno G and Joris I (1995) Apoptosis, oncosis, and necrosis. An overview of cell death. Am. J. Pathol. 146: 3-15

33. Zhu H, Fearnhead HO and Cohen G (1995) An ICE-like protease is a common mediator of apoptosis induced by diverse stimuli in human monocytic THP.1 cells. FEBS Lett. 374: 303-308
34. Srinivasan A, LiF, Wong A, Kodandapani L, Smidt JrR, Krebs JF, Fritz LC, Wu JC and Tomaselli KJ (1998) Bcl-xL functions downstream of caspase-8 to inhibitfasand tumor necrosis factor receptor 1-induced apoptosis of MCF7 breast carcinoma cells. J. Biol. Chem. 273: 4523-4529

35. Zhivotovsky B, Orrenius B, Brustugun OT and Døskeland SO (1998) Injected cytochrome $c$ induces apoptosis. Nature 391: 449-450

36. Honkanen RE, Zwiller J, Moore RE, Daily RE, Daily SL, Khatra BS, Dukelow M and Boynton AL (1990) Characterization of microcystin-LR, a potent inhibitor of type 1 and type 2A protein phosphatases. J. Biol. Chem. 265: 19401-19404

37. Foulkes JG, Strada SJ, Henderson PJ and Cohen P (1983) A kinetic analysis of the effects of inhibitor- 1 and inhibitor-2 on the activity of protein phosphatase-1. Eur. J. Biochem. 132: 309-313

38. Ishihara $\mathrm{H}$, Martin $\mathrm{BL}$, Brautigan $\mathrm{DL}$, Karaki $\mathrm{H}$, Ozaki $\mathrm{H}$, Kato $\mathrm{Y}$, Fusetani $\mathrm{N}$, Watabe S, Hashimoto K, Uemura D and Hartshorne DJ (1989) Calyculin A and okadaic acid: inhibitors of protein phosphatase activity. Biochem. Biophys. Res. Commun. 159: 871-877

39. MacKintosh C and Klumpp S (1990) Tautomycin from the bacterium Streptomyces verticillatus. Another potent and specific inhibitor of protein phosphatases 1 and 2A. FEBS Lett. 277: 137-140

40. Døskeland AP, Vintermyr OK, Flatmark T, Cotton RGH and Døskeland SO (1992) Phenylalanine positively modulates the cAMP-dependent phosphorylation and negatively modulates the vasopressin-induced and okadaic-acidinduced phosphorylation of phenylalanine 4 monooxygenase in intact rat hepatocytes. Eur. J. Biochem. 206: 161-170

41. Lindvall MK, Pihko PM and Koskinen AMP (1997) The binding of Calyculin A to protein phosphatase-1. A novel spiroketal vector model. J. Biol. Chem. 272: 23312-23316

42. Eriksson JE, Toivola D, Meriluoto JA, KarakiH, Han YG and Hartshorne D (1990) Hepatocyte deformation induced by cyanobacterial toxins reflects inhibition of protein phosphatases. Biochem. Biophys. Res. Commun. 173: 1347-1353

43. Matsushima R, Yoshizawa S, Watanabe MF, Harada K, Furusawa M, Carmichael WW and Fujiki $\mathrm{H}$ (1990) In vitro and in vivo effects of protein phosphatase inhibitors, microcystins and nodularin, on mouse skin and fibroblasts. Biochem. Biophys. Res. Commun. 171: 867-874

44. Bertrand R, Solary E, O'ConnorP, Kohn KW and Pommier Y (1994) Induction of a common pathway of apoptosis by staurosporine. Exp. Cell Res. 211: 314-321

45. Harkin ST, Cohen GM and Gescher A (1998) Modulation of apoptosis in rat thymocytes by analogs of staurosporine: lack of direct association with inhibition of protein kinase. Mol. Pharmacol. 54: 663-670

46. Bossy-WetzelE, Newmeyer DD and Green DR (1998) Mitochondrial cytochrome $c$ release in apoptosis occurs upstream of DVED-specific caspase activation and independently of mitochondrial transmembrane depolarization. EMBO J. 17 $37-49$

47. Nagata $S$ (1997) Apoptosis by death factor. Cell $88: 355-365$

48. Nieto MA, González A, Gambón F, Díaz-Espada F and López-Rivas A (1992) Apoptosis in human thymocytes after treatment with glucocorticoids. Clin. Exp. Immunol. 88: 341-344

49. Collins MK, Marvel J, Malde P and Lopez Rivas A (1992) Interleukin 3 protects murine bone marrow cells from apoptosis induced by DNA damaging agents. J. Exp. Med. 176: 1043-1051

50. Duprez E, Gjertsen BT, Bernard O, Lanotte M and Døskeland SO (1993) Antiapoptotic effect of heterozygously expressed mutant RI (Ala 336-Asp) subunit of cAMP kinase I in a rat leukemia cell line. J. Biol. Chem. 268: 8332 8340

51. Russell JH, Masakowski V, Rucinsky T and Phillips G (1982) Mechanisms of immune lysis. III. Characterization of the nature and kinetics of the cytotoxic $T$ lymphocyte-induced nuclear lesion in the target. J. Immunol. 128: 2087-2094

52. Trapani JA, Jans DA, Jans PJ, Smyth MJ, Browne KA and Sutton VR (1998) Efficient nuclear targeting of granzyme $B$ and the nuclear consequences of apoptosis induced by granzyme $B$ and perforin are caspase-dependent, but cell death is caspase-independent. J. Biol. Chem. 273: 27934-27938

53. Atkinson EA, Barry M, Darmon AJ, Shostak I, Turner PC, Moyer RW and Bleackley RC (1998) Cytotoxic T lymphocyte-assisted suicide. Caspase 3 activation is primarily the result of the direct action of granzyme B. J. Biol. Chem. 273: $21261-21266$

54. Buckley CD, Pilling D, Henriquez NV, Parsonage G, Threlfall K, Scheel-Toellner D, Simmons DL, Akbar AN, Lord J and Salmon M (1999) RGD peptides induce apoptosis by direct caspase-3 activation. Nature 397: $534-539$ 
55. Wera S and Hemmings BA (1995) Serine/threonine protein phosphatases. Biochem. J. 311: 17-29

56. Cohen PTW (1997) Novel protein serine/threonine phosphatases: variety is the spice of life. Trends Biochem. Sci. 22: 245-251

57. Bokoch GM (1998) Caspase-mediated activation of PAK2 during apoptosis: proteolytic kinase activation as a general mechanism of apoptotic signal transduction. Cell Death Differ. 5: 637-645

58. Mellgren G, Vintermyr OK and Døskeland SO (1995) Okadaic acid, cAMP and selected nutrients inhibit hepatocyte proliferation at different stages in G1. Modulation of the cAMP effect by phosphatase inhibitors and nutrients. J. Cell. Physiol. 163: 232-240

59. Brustugun OT, Mellgren G, Gjertsen BT, Bjerkvig R and Døskeland SO (1995) Sensitive and rapid detection of $\beta$-galactosidase expression in intact cells by microinjection of fluorescent substrate. Exp. Cell Res. 219: 372-378

60. Mellgren G, Vintermyr OK, Bøe R and Døskeland SO (1993) Hepatocyte DNA replication is abolished by inhibitors selecting protein phosphatase $2 \mathrm{~A}$ rather than phosphatase 1. Exp. Cell Res. 205: 293-301
61. Graessmann M and Graessmann A (1983) Microinjection of tissue culture cells. Methods Enzymol 101: 482-492

62. Cohen $P$ (1989) The structure and regulation of protein phosphatases. Annu. Rev. Biochem. 58: 453-508

63. Vintermyr OK, Gjertsen BT, Lanotte M and Døskeland SO (1993) Microinjected catalytic subunit of cAMP-dependent protein kinase induces apoptosis in myeloid leukemic (IPC-81) cells. Exp. Cell Res. 206: 157-161

64. van Engeland M, Ramaekers FCS, Schutte B and Reutelingsperger CPM (1996) A novelassay to measure loss of plasma membrane asymmetry during apoptosis of adherent cells in culture. Cytometry 24: 131-139

65. Gjertsen BT, Mellgren G, Otten A, Maronde E, Genieser H-G, Jastorff B, Vintermyr OK, McKnight GS and Døskeland SO (1995) Novel (Rp)-cAMPS analogs as tools for inhibition of cAMP-kinase in cell culture. J. Biol. Chem. 270: 20599-20607 